\title{
Rahn Financing in Macroeconomic and Sharia Pawnshops
}

\author{
Roikhan Mochamad Aziz', Acep R. Jayaprawira ${ }^{2}$, Rangga Indwi Pratama ${ }^{3}$ \\ roikhan.ma@uinjkt.ac.id ${ }^{1,2,3}$
}

UIN Syarif Hidayatullah ${ }^{1,2,3}$

\begin{abstract}
This research is aimed to analyse how Rahn financing is affected by macroeconomics and Islamic Pawnshop in Small Medium Entreprise. Multiple regression analysis system is used in this study, which then followed by looking at how Rahn Financing is affected by macroeconomic and sharia mortgage income variables with dynamic analysis while looking at its trend forward (based on graph, increasing or decreasing). Macroeconomic and sharia pawnshop income variables, based on obtained output, are influencing the distribution of sharia pawnshops's Rahn financing in Indonesia significantly. The data frame used is secondary 2007-2017 data from Bank Indonesia and the PT Pegadaian (Persero) annual report. Furthermore, to facilitate the author in retrieving this data, it is sent through internet technology media in the publication of PT Pegadaian Syariah's financial statements and data from Bank Indonesia.
\end{abstract}

Keywords: Dynamic Analysis, Multiple Regression, Rahn, Pawn Shop.

\section{Pendahuluan}

Pegadaian Syariah adalah lembaga keuangan yang secara resmi menyediakan program hipotek kepada publik sebagai alat perbankan alternatif untuk memenuhi kebutuhan masyarakat. Tujuan utamanya adalah untuk memberikan pinjaman atau pembiayaan kepada masyarakat dengan sistem hipotek untuk memenuhi keinginan kebutuhan mereka, baik kebutuhan mendesak dan memenuhi kebutuhan kepuasan individu. Pembiayaan adalah sistem pemberian pinjaman non-perbankan dengan jaminan tertentu di mana jumlah pinjaman yang akan didistribusikan dipengaruhi oleh jumlah jaminan itu sendiri. [1]

Dengan menggunakan basis konvensional maupun syariah, saat ini bank akan melelang berbagai jenis produk dalam workshop. Salah satu produk yang berdasarkan gadai legal oleh gadai hipotek konvensional dengan layanan yang mudah, aman dan cepat sebagai prosedurnya yang disebut KCA pinjaman. Walau terdapat produk bank syariah yang disebut gadai emas syariah, tentu saja pegadaian barang merupakan produk utamanya. Selain gadai emas syariah tersebut, pegadaian syariah juga memiliki produk lain yang merupakan hipotek menggunakan prinsip syariah yang disebut Rahn, di mana pelanggan hanya biaya layanan deposito dan pemeliharaan barang atau Ijarah. [2]

Popularitas perbankan dan asuransi saat ini telah memicu gagasan tersebut. Dengan munculnya bank, asuransi, BMT dan BPR, para sarjana dan praktisi sekarang lebih memperhatikan untuk mendirikan lembaga mereka sendiri. Komoditas ini dianggap dipasok oleh perbankan syariah dengan kehadiran toko-toko syariah, dan bank menyediakan 
pembiayaan kepada publik dalam bentuk pinjaman uang untuk memenuhi kebutuhan mereka. [3]

Pegadaian Islam memiliki produk andalannya, Rahn, Arrum dan Mulia, di mana Rahman menggunakan nilai-nilai Islam yang dialamatkan oleh pelanggan, dan pelanggan hanya dapat menambahkan ijarah, biaya penyimpanan, dan biaya administrasi. Arrum (Ar-Rahn untuk Bisnis Mikro) adalah produk pinjaman yang diberikan kepada pelanggan untuk menggunakan pendekatan pinjaman berjangka untuk menumbuhkan pelanggan bisnis mikro. Prinsip Arrum telah dijamin tetapi konsumen masih dapat menggunakan jaminan untuk kebutuhan operasional mereka. Satu-satunya jaminan, misalnya, dari sepeda motor BPKB, adalah bahwa sepeda motor masih akan digunakan untuk keuntungan. Sementara itu program yang pegadaian tawarkan untuk pelanggan yang berupa penjualan emas disebut Mulia, di mana pembelian yang dilakukan dalam rentang pembayaran atau secara tunai. [4]

Pembentukan distribusi pembiayaan hipotek berdasarkan laporan tahunan untuk 20072017 pada tabel di atas menunjukkan bahwa distribusi pendanaan untuk Arrum dan Mulia tidak sama dengan atau tidak lebih dari distribusi dana untuk Rahn. Karena barang Arrum dan Mulia adalah baru, lebih banyak pelanggan menggunakan produk hipotek syariah terkait dengan harga dan biaya operasional serta barang atau yang pertama kali diidentifikasi kepada masyarakat umum. Dari tujuan ini, untuk menilai dampak krisis, dana Rahn adalah alat yang paling umum digunakan oleh perusahaan dan masyarakat.

Sejak tahun 2007 hingga 2017, jumlah pembiayaan pegadaian syariah terus tumbuh di Indonesia. Di Indonesia, masyarakat yang sebelumnya menggunakan pinjaman ilegal karena Tidak dapat didukung oleh bank, dan karenanya mulai beralih ke pegadaian islam karena pegadaian syariah mempromosikan penyaluran dana dengan kemudahan.

Pada periode 2007-2017, pertumbuhan inflasi Indonesia sangat tidak terduga. Penciptaan pembiayaan yang disalurkan Rahn terus berkembang, dengan pinjaman yang disalurkan sebesar Rp11,5 triliun pada tahun 2015. Sementara itu, inflasi terus berfluktuasi sampai tingkat inflasi 3,35 persen pada tahun 2015, dengan rupiah yang beredar sebesar 4,5 triliun dengan kenaikan harga emas sebesar Rp545.000,00 dan pendapatan dari pegadaian sebesar Rp. 8,8 triliun. Ini menunjukkan bahwa meningkatnya jumlah pembiayaan Rahn yang disalurkan setiap tahunnya dipengaruhi oleh peningkatan harga emas dan pendapatan pegadaian, serta pembiayaan Rahn dipengaruhi oleh jumlah rupiah yang beredar dan fluktuasi inflasi.

Dalam memenuhi kebutuhannya, masyarakat indonesia dipengaruhi oleh fluktuasi tingkat inflasi dengan menaiknya harga dasar dan meningkatnya masalah ekonomi. Untuk itu, diperlukan evaluasi pertumbuhan pembiayaan Rahn atau hipotek syariah setelah krisis 2008 dengan umlah rupiah yang beredar, harga emas, pendapatan bisnis, dan tingkat inflasi sebagai indikator yang memadai. Inflasi berpengaruh pada berapa banyak kredit yang diberikan. Efek dari inflasi adalah melalui tingkat bunga nominal, karena dari tingkat bunga nominal dikurangi inflasi, tingkat bunga riil dibuat. Tingkat bunga riil akan menurun ketika tingkat inflasi tinggi, sehingga menyebabkan peningkatan jumlah distribusi kredit.

Makalah ini akan terbatas untuk periode 2007-2017 pada analisis keadaan pendapatan untuk Pembiayaan Rahn, jumlah uang yang beredar, harga emas, dan inflasi dari PT Pegadaian. Terminologi pertanyaannya:

1. Bagaimana dampak bagian dari ekonomi makro dan pendapatan pegadaian Islam pada komponen distribusi pada periode 2007-2017 oleh PT Pegadaian Syariah (Rahn nya) 
2. Bagaimana variabel makroekonomi dan pegadaian syariah mendapat keuntungan sekaligus mempengaruhi variabel distribusi Rahn pada tahun 2007 hingga 2017 oleh PT Pegadaian Syariah

3. Apa proyeksi pengembangan pembiayaan Rahn oleh Pegadaian Syariah dari 2017 sampai 2027

\section{Metode}

\subsection{Model penelitian}

Jumlah uang beredar, harga emas, laba operasi, dan inflasi dalam pendanaan Rahn merupakan hubungan yang diuji kemudian akan diilihat dampaknya dengan model penelitian yang merupakan hasil dari penggabungan struktur teoretis dari beberapa ahli dari lembaga keuangan. Data yang digunakan untuk kuartal pertama 2007 hingga kuartal keempat 2017 adalah data triwulanan (kuantitatif). Dalam analisis ini, populasi di Indonesia adalah laporan keuangan triwulanan Islam. Dalam laporan ini, analisis tingkat inflasi, laba bisnis, jumlah rupiah serta harga emas PT Pembiayaan Rahn Pegadaian Syariah pada tahun 2007 hingga 2017 diperkirakan. Metode kuantitaif adalah pendekatan yang digunakan, di mana analisis numerik adalah bentuk data yang dikumpulkan. Jenis format kuantitatif dan deduktif yang dimulai dari umum ke yang lebih spesifik digunakan dalam analisis ini. Pengumpulan metode analitis menggunakan Ordinary Least Square (OLS) yang menurut Nachrowi (2006: 9) digunakan seperti Multiple Regression, yaitu untuk melihat pengaruh variabel independen pada variabel dependen, dan Dynamics Check atau tes dinamis guna melihat perkembangan apakah secara bertahap, stabil atau turun, dalam kata lain estimasi jangka panjang..

\subsection{Hipotesis}

1. $\mathrm{HO}=$ Tidak ada dampak besar pada distribusi Rahn di PT Pegadaian Syariah Portion dari 2007-2017 antara variabel pendapatan pegadaian syariah, jumlah uang beredar, harga emas, dan inflasi.

HI = Ada dampak besar pada distribusi Rahn di PT Pegadaian Syariah sebagian dari 2007-2017 antara variabel pendapatan pegadaian syariah, jumlah uang beredar, harga emas, dan inflasi.

2. $\mathrm{HO}=$ Tidak ada dampak besar pada distribusi simultan di PT Pegadaian Syariah untuk periode 2007-2017 antara variabel pendapatan pegadaian syariah, jumlah uang beredar, tingkat emas, dan inflasi.

HI = Ada dampak besar pada distribusi Rahn PT Pegadaian Syariah pada tahun 2007 hingga 2017 antara variabel pendapatan pegadaian syariah, jumlah uang beredar, harga emas, dan inflasi.

3. $\mathrm{HO}=$ Distribusi Rahn oleh pegadaian syariah dari 2017-2027 tidak meningkat

$\mathrm{HI}=$ Penjualan Rahn oleh pegadaian Islam antara 2017-2027 meningkat

c. Metodologi

Secara garis besar, penelitian ini menganalisis dampak pembiayaan PT Pegadaian Syariah Rahn untuk periode 2007-2017 terhadap tingkat inflasi, laba perusahaan, jumlah pelanggan, dan jumlah rupiah yang beredar. 
Untuk mengevaluasi hubungan dan pengaruh dependent variable (variabel dependen) dari beberapa variabel independen, digunakan analisis regresi berganda. Persamaan regresi dengan empat variabel independen adalah dalam bentuk:

$$
\begin{aligned}
& \mathrm{H}=\alpha+\beta \mathrm{L} 1+\beta \mathrm{S}+\beta \mathrm{L} 2+\beta \mathrm{M}+\mathrm{h} \\
& \mathrm{LY}=\alpha+\beta \mathrm{X} 1+\beta \mathrm{X} 2+\beta \mathrm{LX} 3+\beta \mathrm{LX} 4+\varepsilon
\end{aligned}
$$

Sementara model ekonometrik ditulis

Informasi:

H / LY: Rahn Financing

$\alpha$ : Constanta

$\beta 1, \beta 2, \beta 3, \beta 4$ : Koefisien regresi

L1 / X1: Inflasi

S / X2: Pendapatan Operasional

L2 / LX3: Harga Emas

M / LX4: Jumlah Rupiah Yang Beredar

$\mathrm{E} / \mathrm{h}$ : istilah kesalahan (variabel di luar model tetapi tidak mempengaruhi variabel dependen)

Pendapatan pegadaian syariah, jumlah uang beredar, harga emas, dan inflasi merupakan variabel independen yang digunakan oleh penulis dalam analisis ini, sedangkan variabel dependennya adalah pendanaan Rahn.

Rahn atau pegadaian syariah menurut Rais menyimpan rahin atau salah satu aset pelanggan sebagai marhun yang diperoleh atau tanda terima pinjaman atau jaminan atas hutang / pinjaman dan nilai ekonomi barang / marhun tersebut.

Rahn adalah skema perlindungan utang dengan produk yang kita miliki dan uang dapat diterima, atau dari penjualan. Demikian pula, Rahn dapat dianggap sebagai menjaga salah satu aset penjamin sebagai jaminan untuk pinjaman. Barang-barang yang menghasilkan kepentingan ekonomi dan fraksi yang memilikinya dapat berhak atas sebagian besar barang tersebut. Rahn juga merupakan perjanjian untuk menyerahkan barang atau properti Anda sebagai jaminan dalam bentuk emas, permata, mobil atau barang seluler lainnya yang diproduksi oleh Syariah Pegadaian di Indonesia, dalam kemitraan dengan Unit Layanan Gadai Syariah (ULGS) yang dibuat oleh Perum Pegadaian.

Data yang digunakan dalam durasi pengukuran dari kuartal pertama 2007 hingga kuartal keempat 2016 adalah data pembiayaan Rahn yang ditransmisikan dalam bentuk data triwulanan dengan data yang diperoleh dari Laporan Tahunan PT Pegadaian (Persero).

Variabel bebas $(\mathrm{X})$ dalam penelitian ini terdiri dari:

- Inflasi

Data operasional yang digunakan dalam analisis ini dikumpulkan berdasarkan estimasi triwulanan dari Bank Indonesia dan Biro Pusat Statistik, dari triwulan 12007 hingga triwulan 42016 dan dinyatakan sebagai persentase.

- Penghasilan Pegadaian

Data yang digunakan selama periode pengukuran dari kuartal pertama 2007 hingga kuartal keempat 2016 adalah data pendapatan triwulanan yang diperoleh dari laporan tahunan oleh PT Pegadaian (Persero)..

- Harga Emas

Harga emas digunakan karena sebagian besar media yang digunakan dalam Rahn adalah emas, mengabaikan kenyataan bahwa harga emas adalah jumlah uang yang dikeluarkan atau membayar untuk membeli produk atau barang dari emas. Oleh karena itu peneliti perlu melihat apakah harga emas akan berdampak pada pembiayaan Rahn. 
- Jumlah Uang Beredar

Mata uang yang beredar adalah seluruh jumlah uang yang telah dikeluarkan dan diedarkan oleh Bank Sentral. Ada dua jenis mata uang: koin dan uang kertas. Dengan begitu, mata uang sama dengan mata uang yang beredar. Jumlah uang beredar, [5] sementara itu, adalah segala macam uang dalam perekonomian, yaitu jumlah mata uang yang beredar ditambah giro di bank-bank komersial. Pasokan uang atau surplus permintaan dibagi menjadi dua istilah, yaitu dalam arti sempit dan umum.

Sejak kuartal pertama 2007 hingga kuartal keempat 2017, data operasional yang digunakan dalam analisis ini dikumpulkan berdasarkan perhitungan triwulanan dari Badan Pusat Statistik Indonesia dan Bank Indonesia.

\section{Pembahasan}

\subsection{Uji Asumsi Klasik}

Pemeriksaan normalitas digunakan untuk melihat apakah model regresi memiliki distribusi variabel perancu atau residual yang teratur [6]. Pemeriksaan normalitas dilihat dari nilai Asymp. Sym. Sym. Menggunakan Kolmogorov One Sample-Smirnov Test, pada hasil penelitian normalitas. Penentuan normalnya pendistribusian model dari nilai probabilitas lebih besar dari $(0,05)$ Kolmogorov-Smirnov; [5] Hasil yang diperoleh terdapat pada tabel 3.

Tabel 3 Uji normalitas

Tabel Hasil Uji dari Satu - Sampel Uji Komolgorov - Smirnov

One-Sample Kolmogorov-Smirnov Test

\begin{tabular}{|ll|r|}
\hline & & \multicolumn{1}{|c|}{ Unstandardized } \\
Residual
\end{tabular}

a. Test distribution is Normal.

b. Calculated from data.

Berdasarkan uji sampel Kolmogorov-Smirnov Uji Satu-Tabel 3 ditunjukkan dari nilai Asymp. Sym. Sym. (2-tailed), yaitu 0,836>0,05, artinya model studi terdistribusi normal.

\subsection{Uji Autokorelasi}

Tujuan dari uji autokorelasi ini adalah untuk melihat apakah model regresi linier ini mengkorelasikan kesalahan waktu t dengan kesalahan t-1 (sebelumnya). Jika koneksi terjadi, ini hanya masalah autokorelasi [6]. Autokorelasi terjadi karena dari waktu ke waktu hasil berturut-turut saling terkait. Model regresi yang baik adalah model yang bebas dari autokorelasi.

Temuan dapat dilihat pada tabel 4 untuk mengetahui apakah autokorelasi dilihat dari ukuran Durbin-Watson.

Tabel 4 Tabel Hasil Uji Autokorelasi 


\begin{tabular}{|l|r|r|r|r|r|}
\hline Model & \multicolumn{1}{|c|}{$\mathrm{R}$} & R Square & \multicolumn{1}{c|}{$\begin{array}{c}\text { Adjusted R } \\
\text { Square }\end{array}$} & $\begin{array}{c}\text { Std. Error of the } \\
\text { Estimate }\end{array}$ & Durbin-Watson \\
\hline 1 & $.987^{\mathrm{a}}$ & .974 & .971 & .06779 & 1.669 \\
\hline
\end{tabular}

a. Predictors: (Constant), JUB, Inflasi, Pendapatan, Emas

b. Dependent Variable: Rahn

Nilai Durbin-Watson dari tabel di atas menunjukkan nilai 1,669 dan lift ini antara -2 dan +2 yang berarti tidak ada pertanyaan tentang autokorelasi dalam analisis ini.

\subsection{Uji Multikolinieritas}

Untuk memeriksa apakah dalam model regresi terdapat korelasi antara variabel independen (Independen), digunakan uji multikolinearitas ini [6]. Dari analisis produksi, dapat dilihat berdasarkan nilai VIF pada tabel berikut.

Tabel 5 Hasil Uji Multikolonieritas

\begin{tabular}{|l|l|l|}
\hline Variabel & VIF & Keterangan \\
\hline Inflasi & 1.326 & Tidak ada masalah Multikolinearitas \\
\hline Pendapatan & 2.906 & Tidak ada masalah Multikolinearitas \\
\hline Harga Emas & 9.978 & Tidak ada masalah Multikolinearitas \\
\hline $\begin{array}{l}\text { Jumlah Uang } \\
\text { Beredar }\end{array}$ & 8.204 & Tidak ada masalah Multikolinearitas \\
\hline
\end{tabular}

Dari tabel 5, dapat dilihat bahwa semua variabel nilai VIF independen di bawah 10, sehingga dapat disimpulkan bahwa tidak ada masalah multikolonitas dalam model regresi ini, yang berarti bahwa tidak ada hubungan antara variabel independen yang diteliti.

\subsection{Uji Heteroskedastisitas}

Uji heteroskedastisitas bertujuan untuk memeriksa apakah perbedaan varians dari residu ke pengamatan lain ada dalam model regresi ini. Jika varians residual konstan, atau sama, dari satu hasil ke yang lain, itu disebut homoskedasticity, sedangkan jika Anda menemukan variasi, itu disebut heteroskedastisitas. Model regresi yang sukses adalah model regresi heteroskedastik atau keberadaan homoseksualitas [6].

Nilai signifikan dapat dilihat dari uji heteroskedastisitas dengan variabel dependen setelah regresi residu absolut yang dapat ditunjukkan dari tabel berikut.

Tabel 7 Hasil Uji Heteroskedastisitas

\begin{tabular}{|c|c|c|}
\hline Variable & Sig & Keterangan \\
\hline Jumlah Uang Beredar & 0,836 & Tidak ada masalah Heteroscedasticity \\
\hline Harga Emas & 0,409 & Tidak ada masalah Heteroscedasticity \\
\hline Pendapatan & 0,673 & Tidak ada masalah Heteroscedasticity \\
\hline Inflasi & 0,536 & Tidak ada masalah Heteroscedasticity \\
\hline
\end{tabular}

Tabel 7 menunjukkan bahwa semua variabel adalah jumlah uang beredar, harga emas, upah, dan inflasi $>0,05$, menunjukkan bahwa tidak terjadi heteroskedastisitas.

\subsection{Uji Regresi Linier Berganda}

Analisis Regresi adalah analisis pengaruh variabel independen terhadap variabel dependen [6]. Untuk melihat dampak variabel makroekonomi (jumlah uang beredar, harga 
emas, dan inflasi) dan laba syariah hipotek, digunakan model regresi linier berganda pada distribusi 2007 dana Rahn di pegadaian syariah. Hasil regresi linier berganda diilustrasikan pada Tabel 8.

Tabel 8 Hasil Uji Regresi Linier Berganda

Coefficients $^{\mathrm{a}}$

\begin{tabular}{|c|c|c|c|c|c|}
\hline \multirow[t]{2}{*}{ Model } & \multicolumn{2}{|c|}{$\begin{array}{l}\text { Unstandardized } \\
\text { Coefficients }\end{array}$} & $\begin{array}{l}\text { Standardized } \\
\text { Coefficients }\end{array}$ & \multirow[t]{2}{*}{$\mathrm{t}$} & \multirow[t]{2}{*}{ Sig. } \\
\hline & B & Std. Error & Beta & & \\
\hline (Constant) & -9.068 & .614 & & -14.769 & .000 \\
\hline Inflasi & .153 & .067 & .068 & 2.278 & .028 \\
\hline Pendapatan & .157 & .065 & .106 & 2.404 & .021 \\
\hline Emas & 2.357 & .257 & .752 & 9.187 & .000 \\
\hline JUB & .410 & .165 & .185 & 2.491 & .017 \\
\hline
\end{tabular}

a. Dependent Variable: Rahn

Persamaan regresi linier berganda berdasarkan tabel di atas mengandung makna:

$\mathrm{H}=-9.068+0,153 \mathrm{~L} 1+0,157 \mathrm{~S}+2,357 \mathrm{M}+0,410 \mathrm{~L} 2+\mathrm{e}$

$\mathrm{Y}=-9.068+0,153 \mathrm{X} 1+0,157 \mathrm{X} 2+2,357 \mathrm{X} 3+0,410 \mathrm{X} 4+\mathrm{e}$

Berdasarkan Persamaan ini dapat diartikan hal-hal berikut.

1. 9.068 merupakan konstanta negatifnya. Hal ini menunjukkan bahwa jika nilai konstan adalah 0 dalam variabel Jumlah Uang yang beredar, Harga Emas, Pendapatan Pegadaian Islam dan inflasi, maka nilai distribusi Rahn di pegadaian syariah adalah 9.068 pada 2007-2017.

2. Indeks inflasi positif memiliki koefisien regresi 0,153. Ini mengasumsikan bahwa jika inflasi (L1 atau X1) meningkat satu unit selama semua variabel independen lainnya stabil, ini akan meningkatkan nilai distribusi pendanaan Rahn sebesar 0,153 pada 2007 2017.

3. Koefisien Syariah Syariah Earnings Factor (S atau X2) bernilai positif pada 0,157. Diasumsikan bahwa jika laba pegadaian syariah berkurang satu unit selama semua variabel independen lainnya stabil, jumlah pembiayaan Rahn akan meningkat sebesar 0,157 pada $2007-2017$.

4. Untuk emas (M atau X3) koefisien regresi harga variabel memiliki nilai positif 2,357. Artinya, hal ini akan meningkatkan nilai distribusi pembiayaan Rahn sebesar 2.357 jika satu unit menaikkan harga emas dengan syarat semua variabel independen lainnya stabil pada 2007-2017.

5. Koefisien vektor regresi Jumlah uang beredar (L2 atau X4) memiliki nilai positif 0,410. Artinya, jika jumlah uang beredar (dengan semua variabel independen lainnya stabil) meningkat satu unit, hal ini akan meningkatkan jumlah distribusi dana Rahn sebesar 0,410 pada $2007-2017$.

\subsection{Uji Hipotesis}

Uji Signifikan secara Parsial

Uji T digunakan untuk melihat pengaruh signifikan masing-masing variabel independen terhadap variabel dependen (Djarwanto \& Pangestu, 1996: 307). Hasil uji T pada Tabel 9. 
Tabel 9 Hasil Tes T

Coefficients $^{\mathrm{a}}$

\begin{tabular}{|c|c|c|c|c|c|c|}
\hline & \multirow[t]{2}{*}{ Model } & \multicolumn{2}{|c|}{$\begin{array}{c}\text { Unstandardized } \\
\text { Coefficients }\end{array}$} & $\begin{array}{l}\text { Standardized } \\
\text { Coefficients }\end{array}$ & \multirow[t]{2}{*}{$\mathrm{t}$} & \multirow[t]{2}{*}{ Sig. } \\
\hline & & B & Std. Error & Beta & & \\
\hline & (Constant) & -9.068 & .614 & & -14.769 & .000 \\
\hline & Inflasi & .153 & .067 & .068 & 2.278 & .028 \\
\hline 1 & Pendapatan & .157 & .065 & .106 & 2.404 & .021 \\
\hline & Emas & 2.357 & .257 & .752 & 9.187 & .000 \\
\hline & JUB & .410 & .165 & .185 & 2.491 & .017 \\
\hline
\end{tabular}

a. Dependent Variable: Rahn

Dari nilai signifikansi, hasil uji t dapat dilihat berdasarkan tabel 9. Jika sig $(0,05)$ kurang dari nilai signifikansi variabel, tolak HO dan terima $\mathrm{H} 1$, yang berarti bahwa variabel independen sebagian mempengaruhi variabel dependen.

- Inflasi mempengaruhi distribusi pembiayaan Rahn untuk pegadaian syariah, dengan indeks inflasi yang bernilai $0,028<0,05$, yang berarti bahwa pada 2007-2017,

- Vektor pendapatan pegadaian Islam memiliki nilai akal 0,021<0,05, artinya pendapatan Pegadaian Islam mempengaruhi distribusi dukungan Rahn untuk Pegadaian Syariah pada 2007-2017.

- Harga Emas memengaruhi distribusi dana Rahn untuk pegadaian syariah pada 2007-2017, dengan variabelnya yang bernilai $0,0<0,05$.

- Jumlah uang beredar mempengaruhi pegadaian syariah (distribusi dana Rahn nya) pada tahun 2007 hingga 2017, dengan variabel jumlah uang beredar memiliki nilai 0,017<0,05.

Uji Simultan (Uji F)

Dalam menentukan apakah semua variabel independen mempengaruhi variabel dependen digunakan uji simultan atau uji $\mathrm{f}$ ini [6]. Hasil Uji $\mathrm{F}$ ada pada table 10.

Tabel 10 Uji Simultan F

ANOVA ${ }^{\mathrm{a}}$

\begin{tabular}{|rl|r|r|r|r|r|}
\hline Model & & Sum of Squares & df & Mean Square & F & Sig. \\
\hline \multirow{3}{*}{1} & Regression & 6.667 & 4 & 1.667 & 362.620 & $.000^{\mathrm{b}}$ \\
& Residual & .179 & 39 & .005 & & \\
& Total & 6.846 & 43 & & & \\
\hline
\end{tabular}

a. Variabel Dependen: Rahn

b. Predictors: (Constant), JUB, Inflasi, Pendapatan, Emas

Dapat dilihat dari tabel 10 bahwa semua variabel independen memiliki nilai signifikansi 0,00 yang kurang dari 0,05. Ini berarti bahwa pada 2007-2017, menentang HO dan menyetujui H1 berarti bahwa Variabel Makroekonomi dan Pegadaian Syariah akan berdampak pada Distribusi Pembibitan Rahn Islami di Pawnshop.

Determination Coefficient Test (R2) 
Percobaan dan kesalahan menunjukkan berapa banyak variabel independen yang digunakan untuk menggambarkan variabel dependen [7]. Dengan output SPSS, hasil perhitungan untuk nilai R Square (R2) terdapat pada table 11 berikut.

Tabel 11 Hasil perhitungan untuk nilai R Square (R2)

Model Summary

\begin{tabular}{|l|r|r|r|c|}
\hline Model & \multicolumn{1}{|c|}{$\mathrm{R}$} & R Square & $\begin{array}{c}\text { Adjusted R } \\
\text { Square }\end{array}$ & $\begin{array}{c}\text { Std. Error of the } \\
\text { Estimate }\end{array}$ \\
\hline 1 & $.987^{\mathrm{a}}$ & .974 & .971 & .06779 \\
\hline
\end{tabular}

a. Predictors: (Constant), JUB, Inflasi, Pendapatan, Emas

Tabel 11 menunjukkan bahwa nilai R Square adalah 0,974, yang berarti 97 persen dari kemampuan variabel independen untuk menggambarkan variabel dependen. Variabel tertentu di luar variabel yang diamati memperjelas 3 persen sisanya.

\subsection{Uji Dinamis}

Tabel 12 Hasi Uji Dinamis

\begin{tabular}{|c|c|}
\hline Time & Rahn \\
\hline 01 Jan 2017 & $15.001 .153 .742,00$ \\
\hline 01 Jan 2018 & $16.501 .269 .116,20$ \\
\hline 01 Jan 2019 & $18.151 .396 .027,82$ \\
\hline 01 Jan 2020 & $19.966 .535 .630,60$ \\
\hline 01 Jan 2021 & $21.963 .189 .193,66$ \\
\hline 01 Jan 2022 & $24.159 .508 .113,03$ \\
\hline 01 Jan 2023 & $26.575 .458 .924,33$ \\
\hline 01 Jan 2024 & $29.233 .004 .816,76$ \\
\hline 01 Jan 2025 & $32.156 .305 .298,44$ \\
\hline 01 Jan 2026 & $35.371 .935 .828,28$ \\
\hline 01 Jan 2027 & $38.909 .129 .411,11$ \\
\hline
\end{tabular}

Dari dasar Tabel 12 dapat dilihat bahwa dari 2017 hingga 2027, pertumbuhan distribusi dana Rahn akan berlipat ganda. Pada tahun 2027, nilai distribusi ke Rahn sebesar Rp. 38.909.129.411,11 juta rupiah dengan nilai awal sebesar Rp. 15.001.153.752 juta rupiah. 


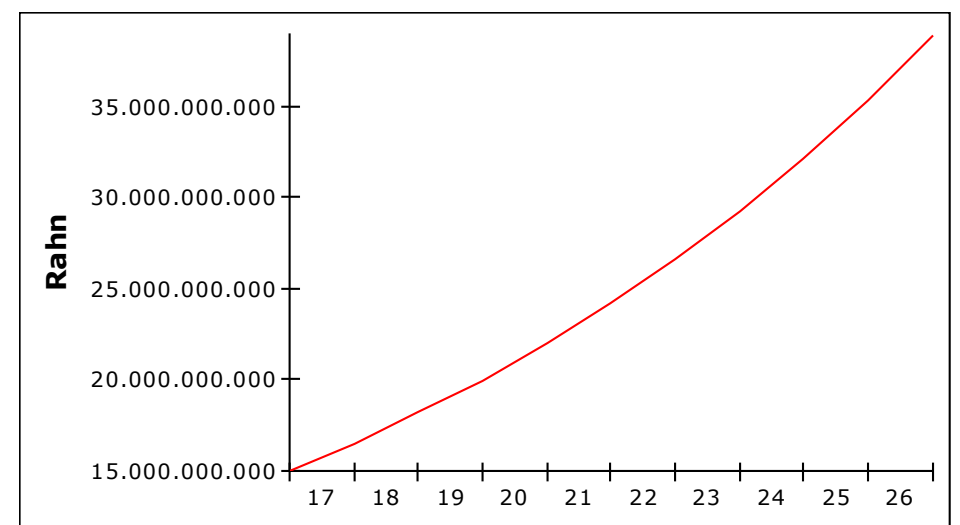

Gambar 1 Rahn Financing Increase from 2007 - 2027

Dari Gambar 1 kita dapat melihat simulasi peningkatan pendanaan Rahn menuju 2027 di 2017.

\subsection{Analisis Ekonomi}

1) Inflasi di Indonesia

Inflasi berarti bahwa biaya semakin meningkat dan dapat dikelola. Hal ini disebabkan meningkatnya permintaan konsumen, likuiditas pasar yang berlebihan dan pengiriman ritel yang lancar. Hal ini juga akan mempengaruhi kenaikan harga komoditas ini. Ini berarti inflasi akan berdampak langsung pada pendanaan yang diterima oleh pegadaian Islam.

Studi sebelumnya, studi Wahyuningsih Dondo [8] yang mengatakan inflasi memiliki efek positif pada distribusi kredit, semakin menegaskan hal ini. Studi Dahlan [9] mengatakan hal yang sama, yaitu Inflasi memiliki efek yang dicairkan pada pendanaan yang kompatibel dengan hasil peneliti pada pengaruh signifikan inflasi pada keuangan Syariah Islam di Indonesia di pegadaian.

2) Meningkatnya Jumlah Uang Beredar

Jumlah total uang yang beredar adalah uang di tangan publik, baik dalam bentuk mata uang, giro, deposito, dan sebagainya. Peningkatan jumlah uang beredar jelas mempengaruhi pendanaan Rahn, karena jika ada banyak uang yang beredar, semua harga komoditas akan segera naik. Ini akan memiliki efek besar langsung pada pendanaan yang dapat didistribusikan.

Berdasarkan temuan para peneliti, jumlah uang yang beredar mempengaruhi pembiayaan Rahn yang disalurkan ke pegadaian Islam. [10]

3) Emas sebagai Modal Investasi dan Bisnis

Emas adalah aset yang melekat yang meningkat dari tahun ke tahun dan nilainya cenderung meningkat dari waktu ke waktu. Emas ini juga dapat digunakan sebagai bentuk investasi atau properti yang dapat dijual dari pegadaian Islam untuk memperoleh modal ventura melalui kontrak Rahn.

Peneliti menemukan bahwa harga emas memiliki dampak besar pada distribusi pembiayaan Rahn di Indonesia melalui pegadaian Islam. Harga emas memiliki dampak signifikan pada distribusi pembiayaan Rahn melalui pegadaian syariah menurut penelitian sebelumnya oleh Danny Febrian [10], yang lebih lanjut mendukung penemuan ini. Selain itu, harga emas memiliki efek positif pada pembiayaan Rahn yang akan didistribusikan di pegadaian syariah. Ini menunjukkan bahwa ketika harga emas naik setiap tahun, semakin banyak orang akan memilih untuk membuat emas mereka tersedia untuk mendapatkan sumber 
daya konsumtif dan ekonomis sehingga distribusi pembiayaan Rahn di pegadaian syariah juga naik menurut Vika Anggun Ratna Pratiwi [3].

4) Pendapatan Pegadaian Syariah Untuk Komunitas Mikro Kecil

Pendapatan pegadaian syariah adalah produk keuntungan dari pegadaian syariah, tergantung pada pembelian yang mereka hasilkan. Semakin besar pendapatan perusahaan, semakin banyak uang yang akan didistribusikan kepada klien, yang memastikan kenaikan dana yang disalurkan akan menghasilkan, karena pendapatan juga tumbuh.

Berdasarkan temuan para peneliti, itu menunjukkan bahwa pendapatan akan mengalami peningkatan dalam distribusi pembiayaan Rahn melalui pegadaian Islam. Pekerjaan terbaru juga mengkonfirmasi, yaitu Widiarti dan Sinarti [11] yang mengatakan bahwa laba bisnis hipotek berpengaruh pada pinjaman hipotetis. Selanjutnya, penelitian dari Purnomo, Febrian [10] dan Anggun [3] di mana mereka juga mengamati temuan yang sama dari penelitiannya, yaitu bahwa pendapatan pegadaian syariah memiliki pengaruh yang signifikan terhadap distribusi pembiayaan Rahn melalui pegadaian Islam di Indonesia.

\section{$4 \quad$ Kesimpulan}

Variabel pendapatan dari pegadaian Islam, jumlah uang yang beredar, harga emas, dan inflasi memiliki pengaruh besar pada distribusi pembiayaan Rahn melalui pegadaian Islam pada 2007-2017, berdasarkan hasil uji-t atau studi parsial. Variabel makroekonomi dan Gadai Islam memiliki pengaruh signifikan pada distribusi pembiayaan Rahn 2007-2017 melalui pegadaian Islam, berdasarkan hasil penelitian F atau studi simultan. Pada 2017-2027, distribusi Rahn tumbuh berdasarkan output dari sistem yang kompleks.

\section{References}

[1] Kashmir, Manajemen Perbankan. Jakarta: PT Raja Grafindo Persada, 2015.

[2] A. Soemitra, Bank \& Lembaga Keuangan Syariah. Jakarta: Kencana, 2009.

[3] A. Vika, Harga Emas Terhadap Pembiayaan Rahn Pada PT Pegadaian Syariah. Jurnal Ekonomi \& Bisnis Universitas Islam Negeri Jakarta, 2015.

[4] A. R. P. T. Pegadaian, 2006.

[5] S. H. Muhamad, Pegadaian Syariah, Edisi Ke 1. Jakarta: Salemba Diniyah, 2003.

[6] W. W. Winarno, Analisis Ekonometrika \& Statistia dengan Eviews, Cetakan Ke 1. Yogyakarta: Sekolah Tinggi Ilmu Manajemen YKPN, 2011.

[7] A. Widarjono, Ekonometrika Pengantar \& Aplikasinya, Edisi Ke 3. Yogyakarta: Ekonesia, 2009.

[8] W. Dondo, Modal Kerja \& Tingkat Inflasi Terhadap Jumlah Alokasi Kredit Modal Kerja Bank Umum di Indonesia, J. Ekon. Pembang. Universitas Sam Ratulangi, 2013.

[9] D. Siamat, Manajemen Lembaga Keuangan, Edisi Ke 5. Jakarta: LPUI, 2005.

[10] D. Febrian, Analisis Pengaruh Tingkat Inflasi, Pendapatan Pegadaian \& Harga Emas Terhadap Pembiayaan Rahn pada PT Pegadaian Syariah di Indonesia.

[11] T. dan S. Widiarti, Pengaruh Pendapatan, Jumlah Nasabah \& Tingkat Inflasi Terhadap Penyaluran Kredit Pada Perusahaan Pegadaian Cabang Batam Periode 2008-2012, J. Jur. Manag. Politek. Negeri Batam, 2013. 